\title{
RESENSI ARTIKEL WIRAUSAHA AGUNG PURNOMO
}

\author{
Bella Silvia
}

Universitas Nahdlatul Ulama Sidoarjo

\section{PENGANTAR}

Resensi atau ulasan dapat membantu pembaca memahami suatu tulisan lebih baik, cepat dan mendalam. Salah satu jenis resensi yaitu resensi artikel. Resensi artikel dalam tulisan ini akan mengulas beberapa tulisan Agung Purnomo terkait wirausaha yang dipublikasikan oleh Institut Teknologi Kreatif Bina Nusantara Malang atau ITK BINUS Malang.

\section{AGUNG PURNOMO}

Agung Purnomo adalah salah satu penulis dan dosen produktif di Indonesia. Ia lahir dan besar di Sidoarjo, Jawa Timur. Semenjak menjadi dosen, ia mulai giat dalam menulis publikasi. Karya-karyanya pernah dimuat di beberapa penerbit nasional, seperti : 
UNUSIDA Press, ITB Press dan STIEBA Madura Press.

\section{KREASI ARTIKEL WIRAUSAHA}

Dalam artikel berjudul "14 Aturan Survive untuk Bisnis Startup” yang terbit pada tahun 2017 ini Agung Purnomo berusaha menyampaikan empat belas tips yang dapat dipakai oleh pengusaha agar dapat bertahan dalam kerasnya bisnis (1). Beberapa tips diantaranya yaitu doa, pemilihan co-founder, hemat, jangan menyerah dan terus melangkah.

Tulisan berjudul "Mengapa Pengusaha Butuh Analisis Website ?" yang terbit pada tahun 2017 tersebut memaparkan analisis website sebagai dasar pemasaran berbasis data dan kunci untuk memahami perubahan situs web atau pemasaran digital yang anda lakukan (2). Artikel menjelaskan analisis website dengan ulasan pemahaman, fungsi, alat, dan fungsi untuk bisnis.

Pemikiran karya Agung Purnomo ini yang berjudul "Mengawali Wirausaha dengan Outsourcing \& Freelancing" terbit tahun 2017 menjelaskan peran 
outsourcing dan freelancing bagi seorang pengusaha bisnis pemula yang tidak pernah ada cukup waktu untuk menyelesaikan semua tugas bisnis (3). Juga diceritakan tentang pemahaman, cara dan manfaat outsourcing dan freelancing bagi para pengusaha pemula.

Goresan tinta bertajuk "Mengenal Fintech sebagai Inovasi Bisnis Keuangan” terbit pada tahun 2017 (4) lebih menitikberatkan pada pemahaman Financial Technolgy atau fintech seperti sebagai program komputer dan teknologi lainnya yang digunakan untuk mendukung atau mengaktifkan perbankan dan jasa keuangan serta pemahaman lainnya. Juga jenis dan daftar perusahaan Fintech di Indonesia. Jika dibaca secara keseluruhan, tulisan ini sangat menarik dan sesuai dengan perkembangan fintech.

Mencengkeramai tulisan bertajuk "Pengertian Edupreneur" terbit pada tahun 2017 (5), membangun banyak kesan dan rasa yang ingin disampaikan. Edupreneur dalam dimaknai menggunakan tiga 
pendekatan yakni wirausaha, pengajar dan proses pendidikan.

Maka begitulah sang penulis Agung Purnomo berusaha menghadirkan wawasan wirausaha dan renungan kepada pembaca dengan tulisan berjudul “Apakah Terlambat untuk Memulai Bisnis” yang terbit pada tahun 2018 (6). Penulis menyajikan informasi biografi 100 orang pendiri perusahaan top dunia pada daftar Forbes sejak umur 35 tahun. Ternyata banyak pengusaha yang sukses ketika memulai usaha di umur yang tidak muda lagi.

Penulis Agung Purnomo terlihat ingin menunjukkan hubungan antara kepedulian sosial dengan wirausaha pada artikel berjudul "Social Entrepreneur: Selamatkan Indonesia dan Dunia dengan Bisnis" yang dikenalkan ke masyarakat pada tahun 2018 (7). Dunia telah sesak dengan masalah sosial dan wirausaha diharapkan mampu membantu mengatasinya melalui social entrepreneur.

Artikel berjudul "Industri 4.0 untuk Wirausaha Jaman Now" yang terbit pada tahun 2019 (8) mengangkat tema tentang tren eksternal industri 
generasi 4.0 yang mempengaruhi seluruh dunia termasuk kepada bidang wirausaha. Pemerintah Indonesia merespon tren ini melalui Making Indonesia 4.0: Indonesia menuju Industri 4.0.

Tulisan bertajuk "Design Sprint: 5 Hari Desain Produk untuk Sukses Wirausaha" (9) menceritakan tentang metode terbaru dalam pengembangan desain produk dalam lima hari yang digagas oleh Google Venture. Karena begitu banyak produk gagal dipasar meskipun telah menghabiskan banyak waktu, tenaga dan pikiran.

Pemikiran dalam tulisan "Mengikuti Jejak Sukses Wirausahawan Jeff Bezos" (10) mengangkat tema bagaimana langkah demi langkah agar bisa menduplikasi metode Jezz Bezos salah satu orang terkaya dunia bisa sukses di bisnis yang dibangun melalui Amazon.

Goresan pemikiran dalam judul "Wirausaha Mendukung Pencapaian SDGs" mengulas tentang peran wirausaha membantu dan mengakselerasi penyelasaian masalah dunia dalam kerangka sustainable development goals atau SDGs (11). 


\section{PENUTUP}

Tulisan-tulisan Agung Purnomo dalam bidang wirausaha cukup membantu kita memahami wirausaha beserta trennya dengan lebih baik dalam bahasa sederhana. 


\section{REFERENCES}

1. Purnomo A. 14 Aturan Survive untuk Bisnis

Startup. Institut Teknologi Kreatif Bina

Nusantara Malang. 2017.

2. Purnomo A. Mengapa Pengusaha Butuh

Analisis Website ?. Institut Teknologi Kreatif

Bina Nusantara Malang. 2017.

3. Purnomo A. Mengawali Wirausaha dengan

Outsourcing \& Freelancing. Institut Teknologi

Kreatif Bina Nusantara Malang. 2017.

4. Purnomo A. Mengenal Fintech sebagai Inovasi

Bisnis Keuangan. Institut Teknologi Kreatif

Bina Nusantara Malang. 2017.

5. Purnomo A. Pengertian Edupreneur. Institut

Teknologi Kreatif Bina Nusantara Malang.

2017.

6. Purnomo A. Apakah Terlambat untuk Memulai

Bisnis ?. Institut Teknologi Kreatif Bina

Nusantara Malang. 2018.

7. Purnomo A. Social Entrepreneur: Selamatkan

Indonesia dan Dunia dengan Bisnis. Institut

Teknologi Kreatif Bina Nusantara Malang. 2018.

8. Purnomo A. Industri 4.0 untuk Wirausaha Jaman Now. Institut Teknologi Kreatif Bina Nusantara Malang. 2019.

9. Purnomo A. Design Sprint: 5 Hari Desain

Produk untuk Sukses Wirausaha. Institut

Teknologi Kreatif Bina Nusantara Malang. 2019. 
10. Purnomo A. Mengikuti Jejak Sukses Wirausahawan Jeff Bezos. Institut Teknologi Kreatif Bina Nusantara Malang. 2019.

11. Purnomo A. Wirausaha Mendukung Pencapaian SDGs. Institut Teknologi Kreatif Bina Nusantara Malang. 2019. 